\title{
GENETIC ENGINEERING OF SEXUAL STERILITY IN SHADE TREES
}

\author{
by Amy M. Brunner', Rozi Mohamed', Richard Meilan', Lorraine A. Sheppard², \\ William H. Rottman ${ }^{3}$, and Steven H. Strauss ${ }^{1}$
}

\begin{abstract}
Shade trees unable to produce floral tissues, or that produce only nonreproductive floral organs such as petals, are desirable for a number of reasons. They can reduce the need to clean flower and fruit litter, eliminate hazards from large and fleshy fruits on walks, and lessen allergenic pollen production. Research in herbaceous species has established that introduction of gene constructs created by recombinant DNA technology provides an effective means to manipulate flowers without deleterious effects on vegetative growth. Though not yet demonstrated in trees, this approach will likely be successful in both angiosperms and gymnosperms because genes that control reproductive development are similar in sequence and function among diverse plant species. Key to the practical application of genetically engineered sterility to shade trees, however, is the development of efficient gene transfer and vegetative propagation systems to deliver engineered, sterile trees to the marketplace; these systems are in place for a limited number of species. We discuss the rationale for sexual sterility in arboriculture, methods for genetic engineering of sterility, our progress in engineering sterility in poplars, and the current status of transformation and propagation methods for some common shade tree genera.

Keywords. Flowering; fruit trees; gene transfer; clonal propagation; transgenes; floral homeotic genes.
\end{abstract}

Genetic transformation is the introduction of new genes, referred to as transgenes, via nonsexual processes. The modified host, a transgenic organism, typically expresses this new transgene and thus possesses a new trait. The entire process of gene isolation, modification, and transfer to a new organism is known as genetic engineering.

Transformation of plants was first accomplished using tobacco in 1984. In the 13 years since then, over 120 species in at least 35 families have been transformed (Birch 1997). In the United States, over 3,500 field trials of transgenic plants are in progress or completed (USDA-APHIS 1997). Furthermore, 29 transgenic crops have been commercially released or approved for release as of December 1997. Transgenes introduced into crops include those conferring resistance to insects, viruses, or herbicides; male sterility; and a wide variety of quality traits such as modified fruit ripening. Genetic engineering is clearly no longer just a scientific research tool; it is making rapid inroads into all areas of agriculture.

Not unexpectedly, the genetic engineering of trees lags well behind that of herbaceous crops. However, substantial progress has been made with several genera. Eight different genera are represented in field tests of transgenic trees, including apple (Malus), plum (Prunus), sweetgum (Liquidambar), and walnut (Juglans) (USDAAPHIS 1997). Furthermore, the commercial potential for genetically engineered trees in commercial tree clones has been clearly demonstrated in poplars (Populus). Introduction of genes conferring resistance to the herbicide glyphosate produced striking results in both greenhouse and field studies (Strauss et al. 1996, 1997). All nontransgenic control trees sprayed with herbicide (Roundup Pro ${ }^{\mathrm{TM}}$ ) were severely damaged, while a large proportion of transgenic lines showed complete or near complete tolerance to the herbicide. Initial results with transgenic poplars expressing a Bacillus thuringiensis toxin gene indicate a high level of resistance to the major pest of poplars, the cottonwood leaf beetle (Strauss et al. 1997). In addition to growth and management traits, wood quality traits, particularly modification of lignin content, are also major areas of research.

Of interest to many arborists is reproductive sterility, a quality trait that has already been successfully introduced into herbaceous species via transformation. The objectives of this paper are to describe the rationale for genetically engineered sterility in shade trees and the methods available to accomplish it. In addition, we cite examples of our progress in engineering sterility in poplars to illustrate the potential, and state-ofthe-art of this technology, for trees. 


\section{Rationale for Sterility}

Though varying in degree among species, fruit litter is often a substantial annoyance (Barker 1986). For example, sweetgum is extensively planted due to desirable traits such as fall leaf color, but the tree's spiny fruits disintegrate very slowly and cause a nuisance on lawns and walks. The fleshy fruits of cherries, plums, and apples often create slippery surfaces and adhere to feet, resulting in floor stains. Senescing fruit of many trees is undesirable to shopkeepers and homeowners because these trees attract insects and disease and cause unpleasant odors. Floral litter, such as from catkins, often passes through screens and contributes to clogging of drains. Though fruit litter can be limited by using only male trees of dioecious species or fruitless cultivars, many desirable shade trees are neither dioecious nor known to have sterile clones (Barker 1986). Finally, elimination of pollen is desirable because many people suffer from allergies induced by tree pollen, an effect which is likely to be exacerbated by fertile trees planted close to homes.

By constraining sexual propagation, sterility can provide several advantages. It would restrict thefts of proprietary germ plasm to vegetative propagules, which can be more easily identified than seedlings by DNA fingerprinting and other methods. Sterile cultivars are more highly contained from unrestricted spread via pollen and seeds, thus greatly minimizing the chances for novel or engineered varieties to escape and become a nuisance in wild or managed environments. This feature is likely to be important to winning regulatory approval for marketing of transgenic varieties of trees (Strauss et al. 1995).

Finally, sterility can provide several other benefits. Trees under stress often produce large fruit crops that may contribute to their vegetative demise; by removing the strain of heavy seed crops, sterility may increase the tolerance of trees to environmental stress (B. McCown, personal communication). Growth regulators have been used to reduce fruit set on ornamental trees (Banko and Stefani 1995; Elam and Baker 1996). However, trees must be sprayed every year, and the chemicals may cause significant injury to vegetative tissues. Additionally, spraying large trees with any chemical, particularly close to homes and commerce, often engenders public opposition. Genetic engineering, on the other hand, should produce long-term, highly reliable sterility without the costs and problems of yearly treatments.

While elimination of entire floral structures is desirable for some trees, this is not the case for trees such as cherry and crabapple, which produce attractive flowers. However, because of the precise mode of action of many floral genes, genetic engineering can be targeted to specific floral organs. Thus, it is possible to engineer a sterile plant that produces normal sepals and petals, as well as to increase the number of petal whorls to enhance attractiveness (described below).

\section{Genetic Engineering of Sterility}

The first steps in the process of genetic engineering are the isolation and manipulation of genes before introduction into a plant (Figure 1, step 1; see Table 1 for definition of terms). Usually, a cDNA rather than a gene is used as a transgene. When a gene is expressed, RNA is transcribed from one strand of DNA. Subsequently, the RNA undergoes modification, including the removal of introns, to produce messenger RNA (mRNA), which is translated into protein. cDNAs can be produced in the laboratory from mRNA isolated from living cells; because they lack introns and are thus smaller than complete genes, they are more easily manipulated (Figure 1, step 2). A promoter is a regulatory DNA sequence that directs the transcription of a gene and is located upstream of the gene it controls, though additional regulatory sequences may be present at other sites. Promoters may be constitutive, directing expression of their genes in virtually all tissues at all times, or they may cause activation only at certain times and/or in certain cell types. Promoters from different kinds of genes can be readily swapped using recombinant DNA methods, providing many options for controlling the expression of transgenes (Figure 1, step 3).

Generation and commercial application of sterile trees requires reliable transformation and propagation systems. This includes a procedure to deliver genes into cells so that the genes may become stably incorporated into the genome (Figure 1, steps 4-5); either Agrobacterium-mediated 
transformation or bombardment with DNA-coated microprojectiles usually serves as the gene transfer agent (Birch 1997; De Block 1993). Other key steps include differentiation of transformed cells with active genes from nontransformed cells (Figure 1, steps 6-7), regeneration of transgenic cells into plants (step 8), molecular methods to verify that the transgene is present in the plant's genome and that mRNA is produced (step 9), the ability to vegetatively (or sexually) propagate a transgenic plant for testing and use (step 10), and verification of its value and delivery of the new trait (step 11).

Woody plants have generally been considered recalcitrant to transformation. However, reliable transformation systems have recently been developed for several difficult agronomic and woody species. For example, cereals were once considered highly difficult to transform, but rice is now routinely transformed, and at least 8 transgenic varieties of maize are in, or near to, commercial use. Efficient transformation systems can be developed for most trees given sufficient effort, as demonstrated by recent advances in transformation of poplars, apples, eucalyptus (Eucalyptus), sweetgum, Prunus, and pines (Pinus) (Table 2).

Sterility methods. Engineered sterility results from either ablation (cell death) of floral tissues, or modification of floral organs due to inhibited expression of genes essential for reproductive development. Ablation methods use a promoter that is active only in floral tissues to regulate the expression of a gene encoding a cytotoxin. Because the cytotoxin is produced only in floral cells and cannot penetrate a cell membrane, floral tissue is destroyed while vegetative tissues are unaffected. In many cases, a
RNase (enzyme that degrades RNA) serves as the cytotoxic gene.

Strategies for inhibiting gene expression act at 1 of 3 levels. Either transcription of the gene is blocked, the mRNA is not translated into protein, or the activity of the encoded protein is inhibited. Usually, a transgene incorporated into a plant's genome is expressed. However, when a promoter or transgene homologous to an native gene is introduced, a proportion of the regenerated transformed plants exhibit gene silencing, also referred to as sense suppression or cosuppression (Flavell 1994; Matzke and Matzke 1995). Expression of both the transgene and endogenous gene is suppressed. In some cases, transcription of the transgene and endogenous gene is inhibited, while in other cases the transcribed mRNAs are degraded before they are translated into protein.

Antisense-suppression is a related phenomenon that acts by either reducing mRNA translation or by increasing mRNA degradation (Mol et al. 1994). A cDNA is placed under the control of a promoter but in an opposite orientation to that of

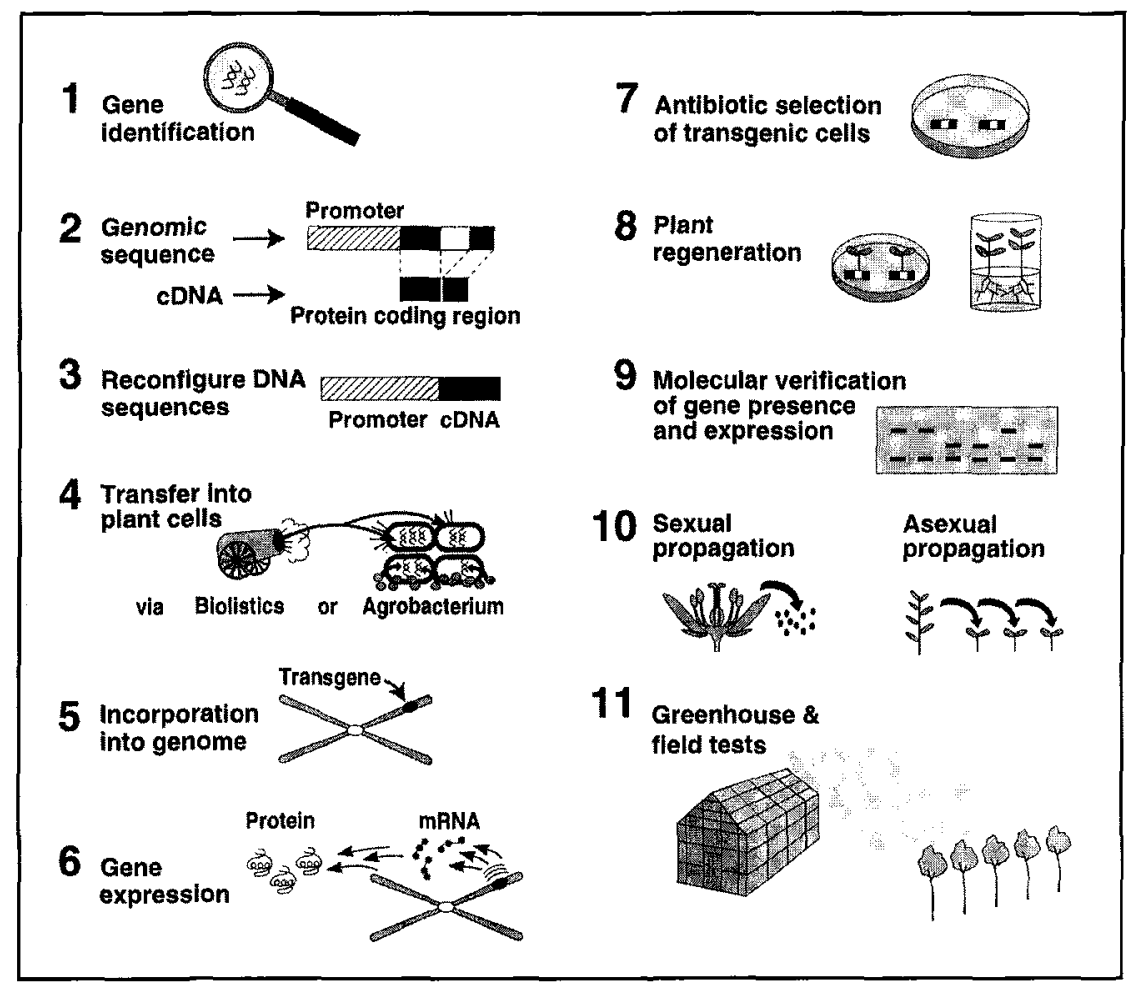

Figure 1. A summary of the steps required to produce transgenic plants. 
Table 1. Glossary of common terms in genetic engineering.

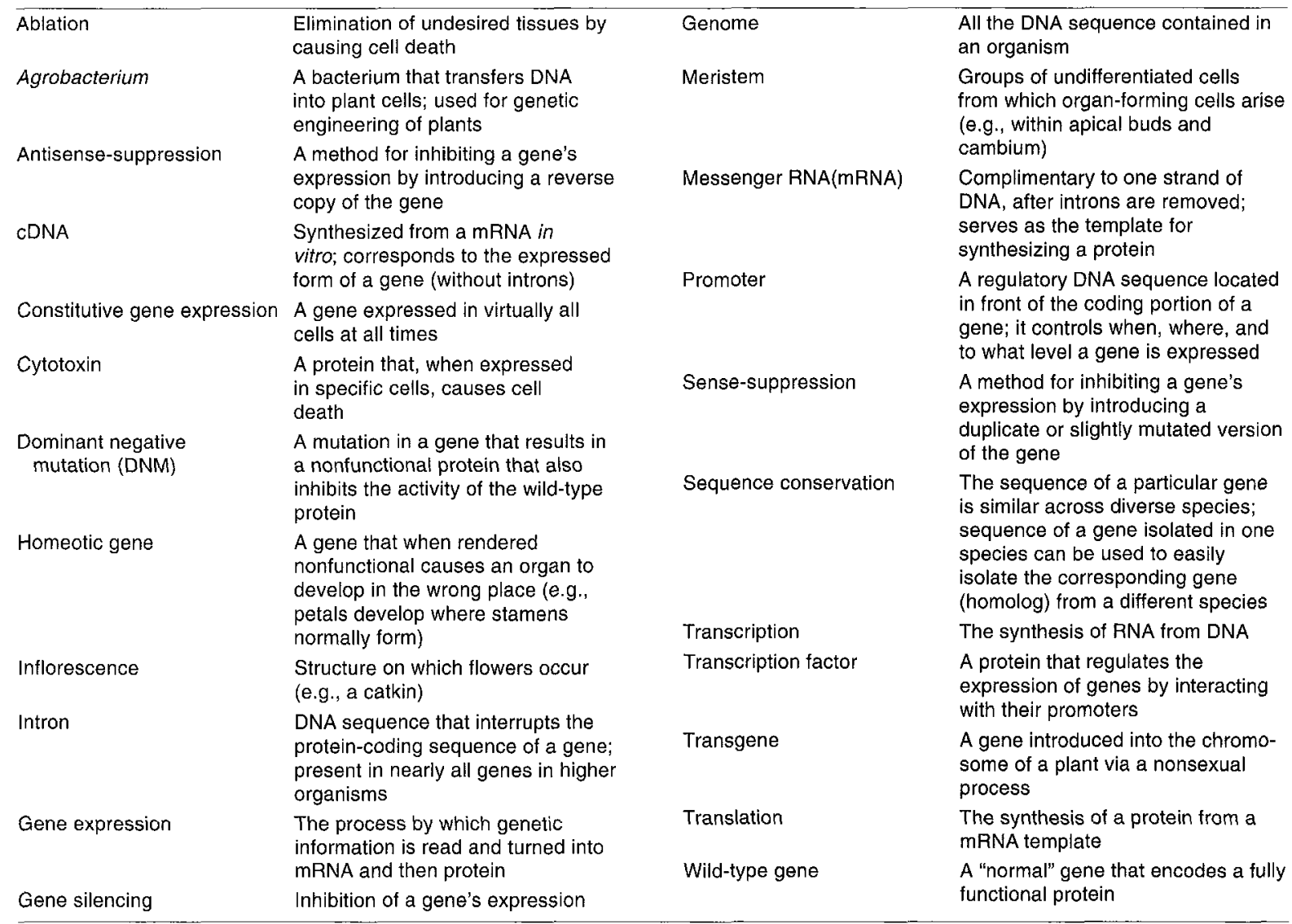

the native gene. As a result, the wrong DNA strand is transcribed, resulting in an antisense mRNA that is not translatable into protein and that is complementary to, and thus inhibits, translation of the endogenous sense mRNA. Gene silencing may be a result of activation of natural systems for cellular defense against aberrant genes and viruses (Ratcliff et al. 1997); however, the mechanisms are not fully understood. Finally, reversion to a nonsuppressed state has been observed in some cases (e.g., Jorgensen 1995), and suppression is often partial, with some gene expression remaining. It is therefore important to test transgenic plants produced by this method thoroughly to ensure the trait is stable.

The final strategy employs transgenes with dominant negative mutations (DNMs). A gene with a DNM encodes a mutant protein that is not only nonfunctional but also inhibits the activity of the coexisting, wild-type protein (Herskowitz 1987). The sequence of a cDNA is altered in vitro to generate a DNM, placed under the control of a strong promoter, and introduced into a plant. Though not yet extensively studied in plants, many DNMs are potent inhibitors of wild-type function in other eukaryotic organisms. The modular structure of regulatory proteins, such as those encoded by floral homeotic genes (described below), makes them particularly useful for generating DNMs.

Floral homeotic genes. To engineer sterility by these methods, promoters of genes expressed only in floral tissues are necessary for the ablation approach, while cDNAs of genes essential for reproductive development are required for the suppression strategies. Floral homeotic genes and their promoters fulfill both of these requirements. Furthermore, their high level of DNA se- 
Table 2. State of transformation, regenerability, and propagation of common shade tree genera.

\begin{tabular}{|c|c|c|c|}
\hline Genus (common name) & Regenerability & Propagation $^{\mathrm{a}}$ & Transformation $^{b}$ \\
\hline Abies (fir) & O, Ec (Mohan et al. 1995b) & $\mathrm{V}, \mathrm{NM}$ & \\
\hline Acer (mapie) & O, E (Grahsl et al. 1991) & $V, M$ & \\
\hline Crataegus (hawthorn) & & $\mathrm{V}, \mathrm{NM}$ & \\
\hline Eucalyptus (eucalyptus) & O, E (Mohan et al. 1995a) & $\mathrm{V}, \mathrm{M}$ & $\begin{array}{l}\text { Macrae and Van-Staden } \\
\text { 1993; Teulieres et al. } 1994\end{array}$ \\
\hline Fraxinus (ash) & O, E (Mohan et al. 1995a) & $\mathrm{V}, \mathrm{M}$ & \\
\hline Larix (larch) & O, E (Bajaj 1992; Mohan et al. 1995b) & $\mathrm{V}, \mathrm{NM}$ & $\begin{array}{l}\text { Huang } 1993 \text {; Huang et al. } \\
\text { 1991; Shin et al. } 1994\end{array}$ \\
\hline Liquidambar (sweetgum) & O, E (Bajaj 1989) & $\mathrm{V}, \mathrm{M}$ & $\begin{array}{l}\text { Chen and Stomp 1991; } \\
\text { Sullivan and Lagrimini } 1993\end{array}$ \\
\hline Liriodendron (Yellow-poplar) & E (Merkle et al. 1993) & $\mathrm{V}, \mathrm{NM}$ & Wilde and Merkle, 1994 \\
\hline Malus (apple, crabapple) & O, $E^{d}$ (Mohan et al. 1995a) & $V, M$ & $\begin{array}{l}\text { Gercheva et al. 1994; } \\
\text { James 1991; Lambert and } \\
\text { Tepfer } 1992\end{array}$ \\
\hline Picea (apruce) & O, E (Mohan et al. 1995b) & $\mathrm{v}$ & Ellis 1993 \\
\hline Pinus (pine) & O, E (Mohan et al. 1995b) & V, NM & Walter et al. 1997 \\
\hline Pistacia (pistache) & E (Onay et al. 1995) & $\mathrm{V}, \mathrm{NM}$ & \\
\hline Platanus (plane tree, sycamore) & $\mathrm{O}^{\prime}$ (Bajaj 1991) & $\mathrm{V}, \mathrm{NM}$ & \\
\hline Poplar (cottonwood, aspen) & O, E (Mohan et al. 1995a) & $\mathrm{V}, \mathrm{M}$ & Han et al. 1996 \\
\hline $\begin{array}{l}\text { Prunus (plum, cherry, } \\
\text { peach, apricot) }\end{array}$ & O, E (Scorza et al. 1995) & V,M & $\begin{array}{l}\text { Camara-Machado and } \\
\text { Camara-Machado 1995; } \\
\text { Scorza et al. } 1995\end{array}$ \\
\hline Pseudotsuga (Douglas-fir) & O, E (Mohan et al. 1995b) & $V, M$ & \\
\hline Quercus (oak) & E (Mohan et al. 1995a) & $\mathrm{V}, \mathrm{NM}$ & \\
\hline $\begin{array}{l}\text { Rhododendron (rhododendron, } \\
\text { azalea) }\end{array}$ & O, Ed (Bajaj 1989) & V, M & \\
\hline Sequoia (Sierra redwood) & O, E (Mohan et al. 1995b) & $V, M$ & \\
\hline Sequoiadendron (coast redwood) & O (Mohan et al. 1995b) & V & \\
\hline Ulmus (elm) & O, Ed (Bajaj 1989; Mohan et al. 1995a) & $V, M$ & Sticklen et al. 1994 \\
\hline
\end{tabular}

apropagation method for commercial purposes (Hartman et al. 1996).

'Key references are listed for genera that have been transformed.

Abbreviations: $O$, organogenesis; $E$, embryogenesis; $V$, vegetative propagation; $M$, micropropagation; $N M$, no commercial micropropagation. 'Only partial or limited success.

quence conservation facilitates isolation of homologous genes from trees.

Floral homeotic genes encode transcription factors that control floral development and have been especially well-studied in the model herbaceous species Arabidopsis thaliana (a member of the mustard family) and Antirrhinum majus (a member of the snapdragon family). Homologs of genes cloned in these 2 species have been isolated and characterized in dicots, monocots, conifers, and ferns, indicating that floral homeotic genes have fundamental roles in reproductive development of all land plants. Studied genes fall into 2 broad functional classes: those controlling meristem identity and organ identity. Floral meristem identity genes mediate the transition from an inflorescence meristem to a floral meristem (Figure 2a). The Arabidopsis genes LEAFY (LFY) and APETALA1 (AP1) are initially expressed throughout the floral meristem, and mutations in these genes cause a transformation of flowers into inflorescence shoots (Weigel and Meyerowitz 1994; Yanofsky 1995). Additional genes have been identified that play at least minor roles in specifying floral meristem identity.

Floral organ identity genes are necessary for 3 different homeotic functions, designated $A, B$ and $C$, which specify the 4 different organ types present in most angiosperms (Figure 2). Each of these activities functions in 2 adjacent whorls: $A$ activity specifies sepals in whorl 1, combined $A B$ activities specify petals in whorl $2, B C$ activities specify stamens in whorl 3 , and $C$ activity specifies carpels in whorl 4. AP1 and APETALA2 are $A$ function genes, APETALA3 (AP3) and PISTILLATAare $B$ genes, and AGAMOUS (AG) is the only known $C$ gene (Weigel and Meyerowitz 1994; Yanofsky 1995). These genes are expressed before the pri- 


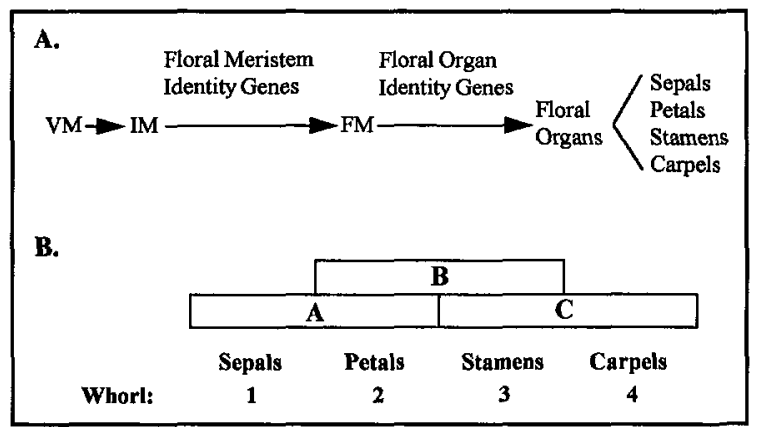

Figure 2. Model for how floral homeotic genes control flower development. (A) Before a plant is able to flower, its vegetative meristem must undergo a transition to an inflorescence meristem. Next, the floral meristem identity genes initiate the formation of floral meristems on the sides of the inflorescence meristem. The floral organ identity genes then direct the differentiation of floral organs from the floral meristem. VM, vegetative meristem; IM, inflorescence meristem; FM, floral meristem. Panel (B) shows the floral organ identity model (Coen and Meyerowitz 1991). The floral meristem of the typical angiosperm is divided into 4 concentric rings or whorls. Each whorl gives rise to a different floral organ. The combinatorial action of 3 classes of floral organ identity genes, designated $A, B$, and $C$, determines what floral organ develops and in which whorl the organ develops. Each class of genes functions in 2 adjacent whorls (indicated by the rectangles).

mordia of the organs they specify emerge from the floral meristem, and organs in 2 adjacent whorls are transformed (e.g., petals are replaced by sepals) if one of these genes is nonfunctional.

$A P 3$ is expressed only in cells giving rise to petals and stamens. When the AP3 promoter was fused to a cytotoxic gene and introduced into tobacco or Arabidopsis, petals and stamens failed to develop, resulting in a flower consisting of 1 whorl of sepals and 1 whorl of carpels (Day et al. 1995). Because AP1 is initially expressed throughout the floral meristem shortly after the meristem begins to form (Gustafson-Brown et al. 1994), introduction of an AP1 promoter-cytotoxin construct may completely ablate all floral organs. In contrast, the expression pattern of $A G$ predicts that an $A G$ promoter-cytotoxin construct will ablate stamens and carpels but not sepal and pet- als. Promoters from nonfloral homeotic genes have also been used to engineer sterility (e.g., Mariani et al. 1990; Goldman et al. 1994). However, these genes are expressed at the last stages of flower development, and promoter-cytotoxin constructs typically prevent either the formation of viable pollen or prevent fertilization of carpels but not both. Thus, these promoters are less versatile than homeotic promoters for engineering a completely sterile plant.

Suppression of floral homeotic genes can also result in bi- or unisexual sterility, as well as generate novel kinds of flowers. Inhibition of $A G$ activity by either DNM or antisense approaches produced completely sterile flowers with a sepal-petal-petal pattern (Mizukami and Ma 1995; Mizukami et al. 1996). Due to $A G$ 's additional role in floral meristem determinacy, this pattern was repeated several times, resulting in particularly attractive flowers. This strategy might be useful for improving attractiveness of Roseaceous tree species (e.g., Prunus, Malus), while eliminating development of their fleshy fruits. In AP3 mutants, sepals and carpels develop normally, but sepals develop in place of petals in the second whorl and carpels develop in place of stamens in the third whorl, resulting in a male-sterile flower with a sepal-sepalcarpel-carpel pattern. When both $L F Y$ and $A P 1$ are inactive, all flowers are transformed into completely sterile inflorescence shoots (Weigel and Meyerowitz 1994; Yanofsky 1995).

Early flowering. The prolonged juvenile phase of trees is a major obstacle to evaluation of recombinant gene constructs for sterility. In some species, such as apple and eucalyptus, chemical and physical treatments that induce precocious and heavy flowering are used routinely. Though similar methods may be effective in additional species, at least 1 to 3 years are still likely to be required before flowering. Recently, an additional approach that uses floral homeotic genes was demonstrated. Several genes that are normally involved in floral initiation and development can induce precocious flowering when constitutively expressed (Nilsson and Weigel 1997). When the Arabidopsis gene LFY was constitutively expressed in aspen ( $P$. tremula $\times P$. tremuloides), flowering occurred within months 


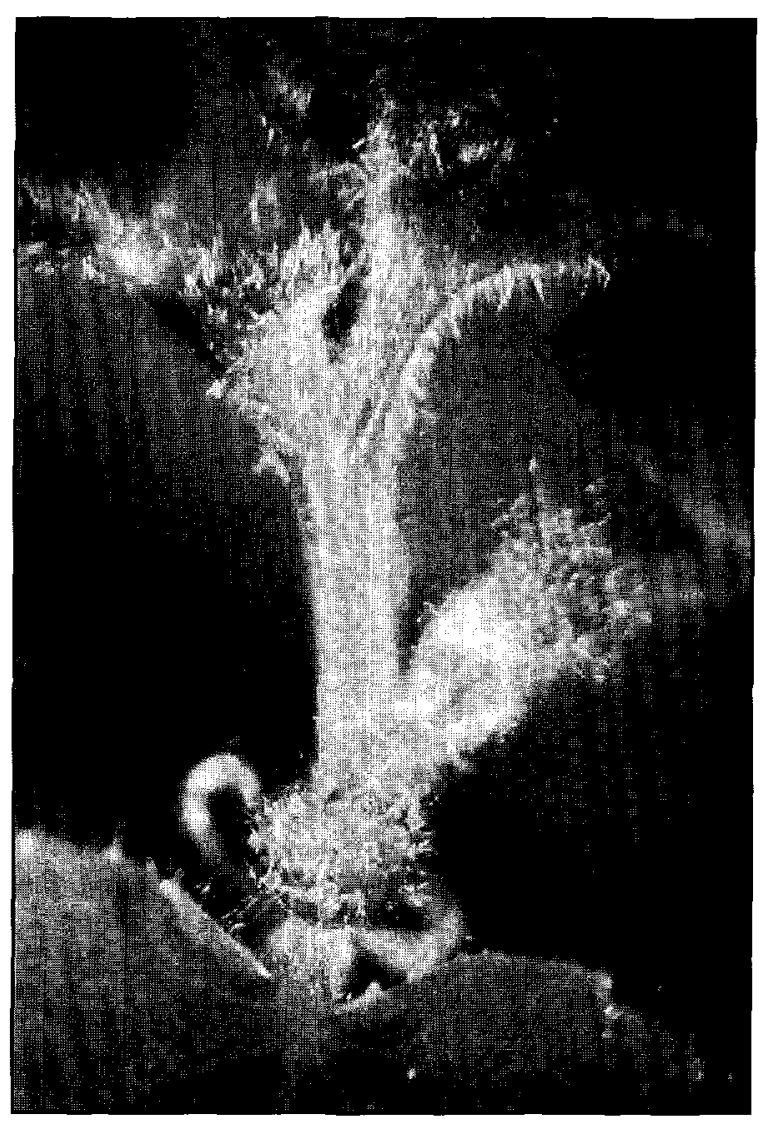

Figure 3. Transgenic early-flowering poplar. A male hybrid ( $P$. tremula $\times P$. tremuloides) was engineered to constitutively express the $L E A F Y$ gene from Arabidopsis (gene was provided by D. Weigel, Scripps Institute). Photo was taken 7 months after the gene was introduced via Agrobacteriummediated transformation. Plant shown is about 13 cm (5 in.) tall; single flowers are seen in the axils of leaves. Normally, inflorescence meristems first arise in leaf axils, followed by initiation of floral meristems along the flanks of the developing inflorescence (i.e., the catkin). The stamens are clearly visible; the perianth cup is a disc-like structure at the base of the flower that is homologous to sepals and/or petals, but is mostly obscured by the stamens.

following transformation (Figure 3; Weigel and Nilsson 1995), though it appeared to be effective only in selected poplar genotypes (unpublished data). Flowers were normal in appearance; however, they formed directly from vegetative meristems in the absence of inflorescence shoots.

\section{Progress Engineering Sterility in Poplars}

Because floral homeotic genes are substantially conserved among species, it is possible that heterologous genes and promoters can be used to engineer sterility in poplars and other trees. However, there are significant risks with this approach. The distinct morphology and development of poplar flowers compared to that of all the well-studied herbaceous species suggests that important differences in gene expression and function will occur. Promoters and genes from another tree with similar morphology, particularly one belonging to the same family, are more likely to work predictably.

For these reasons, we have chosen to focus on poplar floral homeotic cDNAs and promoters for use in engineering sterility. We have isolated 4 cDNAs and genomic clones (genes and promoters) from Populus trichocarpa (black cottonwood) that are homologous to genes well-characterized in Arabidopsis and Antirrhinum (Table 3). Not unexpectedly, we have detected differences in expression and function between the poplar genes and herbaceous homologs. Based on the expression patterns of the poplar genes as well as the function of homologs, we are generating constructs for engineering sterility.

We are using these cDNAs and the floral-specific promoters to engineer sterility via promotercytotoxin, antisense, and DNM approaches. Because inhibition of multiple homeotic genes may yield more complete and stable sterility than single gene inhibition, we plan to also produce constructs designed to inhibit 2 or more genes. For the ablation approach, we have examined various tissues for gene expression and are us-

Table 3. Summary of 4 poplar floral homeotic genes. $(+)=$ gene expression detected; $(-)=$ gene expression not detected; $(++)=$ gene expression detected at a higher level.

\begin{tabular}{llllll}
\hline \multirow{5}{*}{$\begin{array}{l}\text { Poplar } \\
\text { gene }\end{array}$} & \multicolumn{2}{l}{$\begin{array}{l}\text { Expression in } \\
\text { developing flowers }\end{array}$} & $\begin{array}{l}\text { Vegetative } \\
\text { Female }\end{array}$ & Male & Arabidopsis \\
expression & homolog \\
\hline PTFL & ++ & ++ & + & LFY \\
PTD & + & ++ & - & $A P 3$ \\
PTAG1 & ++ & ++ & + & $A G$ \\
PTAG2 & ++ & ++ & + & $A G$ \\
\hline
\end{tabular}


ing promoters of genes for which only floral expression has been detected. However, whether a promoter will direct stringently floral-specific expression of a cytotoxin through many growing seasons and environments is uncertain. Use of an endogenous promoter also risks gene silencing, so that the cytotoxin is not expressed. Finally, the function of poplar genes may differ significantly from homologs in model species, so suppression of these genes does not produce the desired result. By empirically testing a number of sterility constructs, we expect to identify at least a few that result in stable and useful sterility even if these problems occur.

To expedite analysis of sterility constructs, we are also investigating ways to produce early-flowering poplars (Strauss et al. 1996). Five heterologous genes shown to induce early flowering when constitutively expressed are being analyzed in transgenic poplars. To date only the $L F Y$ transgene has caused precocious flowering as previously reported (Weigel and Nilsson 1995), and only in specific genotypes of male poplars (Figure 3). However, aberrant carpel-like structures have been occasionally observed in female transgenic poplars. Surprisingly, constitutive expression of the poplar $L F Y$ homolog, PTFL, has not induced early flowering after 3 years (LFY induced flowering within months). This suggests that poplars have evolved mechanisms different from those present in Arabidopsis to control the initiation of flowering.

\section{Summary}

We reviewed the rationale and methods for genetic engineering of sterility in trees. Advances in the molecular biology of flowering in herbaceous species show that genetic engineering of sterility in shade trees is feasible. Engineered sterility can relieve the substantial problems of fruit litter and pollen production, facilitate regulatory approval for transgenic trees, and obviate the need for flower control via application of growth-regulating chemicals. Sterility that affects one or both sexes, and that can impair the reproductive organs (stamens, carpels) while preserving or enhancing floral display organs (perianth), can be accomplished with current technology. Gene transfer and propagation methods exist for many genera to a sufficient degree to enable successful application of this technology. Among common temperate shade trees, methods are most advanced for Malus, Populus, Prunus, Liquidambar, and Eucalyptus. Progress in isolation, configuration, and testing of floral genes from trees is most advanced in poplars and will provide a model and source of transgenes for genetic engineering of other woody species.

\section{Literature Cited}

Bajaj, Y.P.S. (Ed.) 1989. Biotechnology in Agriculture and Forestry, Vol. 5: Trees II, Springer-Verlag, Berlin.

Bajaj, Y.P.S. (Ed.) 1991. Biotechnology in Agriculture and Forestry, Vol. 16: Trees III, Springer-Verlag, Berlin.

Bajaj, Y.P.S. (Ed.) 1992. Biotechnology in Agriculture and Forestry, Vol. 18: High-Tech and Micropropagation II, Springer-Verlag, Berlin.

Banko, T.J., and M. Stefani. 1995. Growth regulators for management of fruit production on American sweetgum. J. Arboric. 21:88-89.

Barker, P.A. 1986. Fruit litter from urban trees. J. Arboric. 12:293-298.

Birch, R.G. 1997. Plant transformation: Problems and strategies for practical application. Annu. Rev. Plant Physiol. Plant Mol. Biol. 48:297-326.

Camara-Machado, A.-da, and M. Laimer-da CamaraMachado. 1995. Genetic transformation in Prunus armeniaca L. (Apricot). Biotechnol. Agricult. For. 34:240-253.

Coen, E.S., and E.M. Meyerowitz. 1991. The war of the whorls: Genetic interactions controlling flower development. Nature 353:31-37.

Chen, Z.Z., and A.M. Stomp. 1991. Transformation of Liquidambar styraciflua L. using Agrobacterium tumefaciens. Southern Forest Tree Improvement Conference, June 17-20, Knoxville, TN.

Day, C.D., B.F.C. Galoci, and V.F. Irish. 1995. Genetic ablation of petal and stamen primordia to elucidate cell interactions during floral development. Development 121:2887-2895.

De Block, M. 1993. The cell biology of plant transformation: Current state, problems, prospects and the implications for the plant breeding. Euphytica 71:1-14.

Elam, P., and J. Baker. 1996. Fruit inhibition in Quercus species using growth regulators. J. Arboric. 22:109-110. 
Ellis, D. 1993. Transformation in spruce (Picea species). Biotechnol. Agricult. For. 23:316-330.

Flavell, R.B. 1994. Inactivation of gene expression in plants as a consequence of specific sequence duplication. Proc. Natl. Acad. Sci. 91:3490-3496.

Gercheva, P., R.H. Zimmerman, L.D. Owens, C. Berry, and F.A. Hammerschlag. 1994. Particle bombardment of apple leaf explants influences adventitious shoot formation. Hortscience 29 (12):1536-1538.

Goldman, M.H., R.B. Goldburg, and C. Mariani. 1994. Female sterile tobacco plants are produced by stigma-specific cell ablation. EMBO J. 13:29762984.

Grahsl, A., J. Schmidt, and E. Wilhelm. 1991. Somatic embryogenesis and organogenesis of embryonic explants of Abies alba and Acer pseudoplatanus. NATO ASI Ser. Ser. A Life Sci. 210:201-203.

Gustafson-Brown, C., B. Savidge, and M.F. Yanofsky. 1994. Regulation of the Arabidopsis floral homeotic gene APETALA1. Cell 76:131-143.

Han K.-H., M.P. Gordon, and S.H. Strauss. 1996. Cellular and molecular biology of Agrobacteriummediated transformation of plants and its application to genetic transformation of Populus, pp 201-216. In Stettler, R.F., H.D. Bradshaw, P.E. Heilman, and T.M. Hinckley (Eds.). Biology of Populus and Its Implications for Management and Conservation. NRC Research Press, Ottawa, ON, Can.

Hartman H.T., D.E. Kester, F.T. Davies Jr., and R.L. Geneve. 1996. Plant Propagation: Principles and Practices (6th ed.). Prentice-Hall, Englewood Cliffs, NJ. pp. 667-724.

Herskowitz, I. 1987. Functional inactivation of genes by dominant negative mutations. Nature 329:219222.

Huang, Y. (Ed.) 1993. Genetic Engineering of Larix Decidua: Agrobacterium-Mediated Gene Transfer and Regeneration of Transgenic Plants in European Larch. UMI Publishing Company, Ann Arbor, MI. $245 \mathrm{pp}$.

Huang, Y., A.M. Diner, and D.F. Karnosky. 1991. Agrobacterium rhizogenes-mediated genetic transformation and regeneration of a conifer: Larix decidua. In Vitro Cell. and Dev. Biol.-Plant 27:201207.

James, D.J. 1991. Agrobacterium-mediated transformation of apple (Malus pumila Mill). NATO ASI Ser. Ser. A Life Sci. 210:213-226.

Jorgensen, R.A. 1995. Cosuppression, flower color patterns and metastable gene expression states. Science 268:686-691.
Lambert, C., and D.Tepfer. 1992. Use of Agrobacterium rhizogenes to create transgenic apple trees having an altered organogenic response to hormones. Theor. Appl. Genet. 85(1):105-109.

Macrae, S., and J. Van-Staden. 1993. Agrobacterium rhizogenes-mediated transformation to improve rooting ability to eucalypts. Tree Physiol. 12(4):411418.

Mariani, C., M. De Beuckeleer, J. Truettner, J. Leemans, and R.B. Goldburg. 1990. Induction of male sterility in plants by a chimaeric ribonuclease gene. Nature 347:737-741.

Matzke, M.A., and A.J.M. Matzke. 1995. Homologydependent gene silencing in transgenic plants: What does it really tell us? Trends Genet. 11:1-3.

Merkle, S.A., M.T. Hoey, B.A. Watson-Pauley, and S.E. Schlarbaum. 1993. Propagation of Liriodendron hybrids via somatic embryogenesis. Plant Cell Tiss. Org. Cult. 34:191-198.

Mizukami, Y. and H. Ma. 1995. Separation of AG function in floral meristem determinancy from that in reproductive organ identity by expressing antisense AG RNA. Plant Mol. Biol. 28:767-784.

Mizukami, Y., H. Huang, M. Tudor, Y. Hu, and H. Ma. 1996. Functional domains of the floral regulator AGAMOUS: Characterization of the DNA binding domain and analysis of dominant negative mutations. Plant Cell 8:831-845.

Mohan, S.J., P.K. Gupta, and R.J. Newton, (Eds.). 1995a. Somatic Embryogenesis in Woody Plants: Vol. 2-Angiosperms, Kluwer Academic Publ., The Netherlands.

Mohan, S.J., P.K. Gupta, and R.J. Newton. (Eds.). 1995b. Somatic Embryogenesis in Woody Plants: Vol. 3-Gymnosperms, Kluwer Academic Publ., The Netherlands.

Mol, J.N.M., R.Van Blokland, P. De Lange, M. Stam, and J.M. Kooter. 1994. Post-transcriptional inhibition of gene expression: Sense and antisense genes, pp 309-334, in Paszkowski, J. (Ed.). Homologous Recombination and Gene Silencing in Plants. Kluwer Academic Publ., The Netherlands.

Nilsson, O., and D. Weigel. 1997. Modulating the timing of flowering. Curr. Opin. Biotech. 8:195-199.

Onay, A., C.E. Jeffree, and M.M. Yeoman. 1995. Somatic embryogenesis in cultured immature kernels of Pistachio, Pistacia vera L. Plant-CellRep. 15:192-195.

Ratcliff, F., B.D. Harrison, and D. Baulcombe. 1997. A similarity between viral defense and gene silencing in plants. Science 276:1558-1560. 
Scorza, R., F.A. Hammerschlag, T.W. Zimmerman, and J.M. Cordts. 1995. Genetic transformation in Prunus persica (Peach) and Prunus domestica (Plum). Biotechnol. Agricult. For. 34:253-268.

Shin, D.I., G.K. Podila, and D.F. Karnosky. 1994. Genetic transformation in Larix species (Larches). Biotechnol. Agricult. For. 29:321-334.

Sticklen, M.B., R.K. Hajela, M.G. Bolyard, L.S. Graham, J.L. and Sherald. 1994. Genetic transformation in Ulmus species (E/ms). Biotechnol. Agricult. For. 29:401-408.

Strauss, S.H., W.H. Rottmann, A.M. Brunner, and L.A. Sheppard. 1995. Genetic engineering of reproductive sterility in forest trees. Mol. Breed. 1:1-22.

Strauss, S.H., K.-H. Han, R. Meilan, S. DiFazio, A. Brunner, L. Sheppard, and R. James. 1996. Tree Genetic Engineering Research Cooperative (TGERC) Annual Report: 1995-1996. Forest Research Laboratory, Oregon State University, Corvallis.

Strauss, S.H., R. James, A. Brunner, S. DiFazio, and R. Meilan. 1997. Tree Genetic Engineering Research Cooperative (TGERC) Annual Report: 1996-1997. Forest Research Laboratory, Oregon State University, Corvallis.

Sullivan, J., and Lagrimini, L.M. 1993. Transformation of Liquidambar styraciflua using Agrobacterium tumefaciens. Plant Cell Rep. 12:303-306.

Teulieres, C., C. Marque, and A.M. Boudet. 1994. Genetic transformation of Eucalyptus. Biotechnol. Agricult. For. 29:289-307.

USDA-APHIS, Biotechnology and Scientific Services. 1997. http:/www.aphis.usda.gov/biotech/(Dec. 20, 1997).

Walter, C., L.Grace, A. Loenneborg, H. Kvaalen, A. Wagner, E. Mellerowicz, and A. Walden. 1997. Genetic engineering of conifer species: Transformation and gene expression with transgenic tissues and trees. Joint Meeting of the IUFRO Working Parties 2.04-07 and 2.04-06 Somatic Cell Genetics and Molecular Genetics of Trees, Aug. 12-16, Quebec City, QC, Can.

Weigel, D., and E.M. Meyerowitz. 1994. The ABCs of floral homeotic genes. Cell 78:203-209.

Weigel, D., and O. Nilsson. 1995. A developmental switch sufficient for flower initiation in diverse plants. Nature 377:495-500.

Wilde, H.D., and S.A. Merkle. 1994. Genetic transformation in Liriodendron tulipifera $\mathrm{L}$. (yellow poplar). Biotechnol. Agricult. For. 29:337-347.
Yanofsky, M.F. 1995. Floral meristems to floral organs: Geries controlling early events in Arabidopsis flower development. Annu. Rev. Plant Physiol. Plant Mol. Biol. 46:167-188.

Acknowledgements. We thank Phil Barker for introducing us to this area and helping to recommend contacts and literature; Deborah and Brent McCown, Tony Chen, Gayle Suttle, Lynne Caton, and Bill Anderson for advice on the potential importance of sterility to arboriculture; Bryan Kaphammer and Daniel Carraway for information about sweetgum transformation; and NSF, EPA, USDA NRI, and the Oregon State University Tree Genetic Engineering Research Cooperative for research support.

\section{${ }^{\prime}$ Department of Forest Science \\ Oregon State University \\ Corvallis, OR 97331-7501}

${ }^{2}$ Current address:

USDA-Forest Service

Department of Environmental Horticulture

University of California

1 Shields Avenue

Davis, CA 95616

${ }^{3}$ Current address:

Westvaco Forest Research

Box 1950

Summerville, SC 29484 
Résumé. Les arbres ornementaux incapables de produire des tissus floraux ou qui ne produisent que des organes floraux non reproducteurs sont recherchés pour diverses raisons. Ils peuvent réduire les besoins en ramassage de fleurs tombées, éliminer les risques d'accidents provoqués par de gros fruits charnus sur les trottoirs, diminuer les besoins en ressources chez les arbres en stress physiologique, et diminuer la production en pollen allergène. La recherche chez les espèces herbacées a permis de prouver clairement que la technologie d'introduction de gènes reconstruits, grâce une recombinaison de l'ADN, fournit un excellent moyen pour manipuler les structures florales sans effet secondaire sur la croissance végétative. Même si ce n'est pas encore démontré pour les arbres, cette approche semble être promettante à la fois chez les angiospermes et les gymnospermes parce que les gènes contrôlant le développement reproductif sont conservés parmi les diverses espèces de plantes. La clé pour l'application de la stérilité génétique aux arbres ornementaux est le développement de systèmes de propagation végétative et de manipulation efficace pour fournir des arbres stériles sur le marché. On y discute de la rationalité d'un stérilité sexuelle en arboriculture, des méthodes de stérilité en génie génétique, des progrès pour rendre stérile les peupliers et de l'état d'avancement des méthodes de propagation et de manipulation chez certains genres communs d'arbres.

Zusammenfassung. Schattenbäume, die keine Blüten oder die nur unfruchtbare Blüten ausbilden, sind aus zahlreichen Gründen wünschenswert. Sie können die Notwendigkeit des Säuberns von Blütenabfällen minimieren, die Unfallgefahr durch große und fleischige Früchte ausschließen, die Drain-workung physiologisch gestresster Bäume auf ihre Recourcen reduzieren und die Produktion von allergieverursachenden Pollen wird verhindert. Die Erforschung der Pflanzenarten hat eindeutig ergeben, daß die Einführung von Genkonstruktionen, die mittels DNATechnologie enstanden sind, ein effektives Mittel zur Manipulation von Blütenstrukturen darstellen, ohne nachteilige Effekte auf das vegetative Wachstum zu haben. Awch wenn es bei Bäumen noch nicht demonstriert wurde, scheint dieser Versuch doch bei Nackt- und Bedecktsamern erfolgreich zu sein weil die Gene, die die Reproduktion kontrollieren, in verschiedenen Pflanzenarten vorkommen. Der Schlüssel zur praktischen Anwendung von genetisch konstruierter Sterilität ist die Entwicklung von effizienter Transformation und vegetativer Vermehrungstechnik, um dem Markt einen technisch ausgereiften sterilen Baum anzubieten. Wir besprechen hier die Argumente für sexuelle Sterilität, unsere Fortschritte bei der technischen Sterilisierung von Pappein und den gegenwärten Stand der Transformation und Vermehrungstechnik bei einigen häufig vorkommenden Arten von Schattenbäumen.

Resumen. Los árboles de sombra que no producen tejidos florales, o que producen solamente órganos florales reproductivos, son deseables por un número de razones. Ellos reducen la necesidad de barrer sus flores, eliminan los peligros de grandes y carnosos frutos sobre las aceras, reducen el drenaje de recursos de árboles fisiológicamente estresados y aminoran la producción de polen alergeno. La investigación con especies herbáceas tiene claramente establecido que la introducción de genes creados por la tecnología de recombinación de DNA provee un medio efectivo para manipular las estructuras florales sin deteriorar el crecimiento vegetativo. Aunque no ha sido aún demostrado en los árboles, esta aproximación es probable de ser exitosa en angiospermas y gimnospermas, debido a que los genes que controlan el desarrollo reproductivo están conservados entre diversas especies de plantas. La clave para la aplicación práctica de la ingeniería genética de la esterilidad para los árboles de sombra es el desarrollo de eficientes sistemas de propagación vegetativa y transformación para llevar árboles estériles al mercado. Discutimos la razón de la esterilidad sexual en arboricultura, los métodos para la ingeniería genética de la esterilidad, nuestros avances en ingeniería de la esterilidad en álamos, y el estado actual de la transformación y métodos de propagaciójn para algunos géneros comunes de árboles de sombra. 